\title{
Genesis of Megacrystalline Uraninite: A Case Study of the Haita Area of the Western Margin of the Yangtze Block, China
}

\author{
Zhengqi Xu ${ }^{1,2,3, *}$, Minghui Yin ${ }^{1,3, *}$, Youliang Chen ${ }^{2,3}$, Lu Xiang ${ }^{3}$, Hao Song ${ }^{1,2,3}$, Chengjiang Zhang ${ }^{1,2,3}$, \\ Jian Yao ${ }^{4}$ and $\mathrm{Hu}$ Guo ${ }^{5}$ \\ 1 Earth Exploration and Information Technology Key Laboratory of Ministry of Education, \\ Chengdu University of Technology, Chengdu 610059, China; songhhao@yeah.net (H.S.); \\ zcj@cdut.edu.cn (C.Z.) \\ 2 Sichuan Key Laboratory of Geoscience and Nuclear Technology, Chengdu University of Technology, \\ Chengdu 610059, China; chenyouliang09@cdut.cn \\ 3 College of Earth Sciences, Chengdu University of Technology, Chengdu 610059, China; xianglucc@163.com \\ 4 No. 280 Research Institute, China National Nuclear Corporation, Guanghan 618300, China; \\ yaojian280@163.com \\ 5 Tianjin Center, China Geological Survey, Tianjin 300170, China; 028huguo@163.com \\ * Correspondence: xuzhengqi@cdut.cn (Z.X.); 2019010021@stu.cdut.edu.cn (M.Y.)
}

Citation: Xu, Z.; Yin, M.; Chen, Y.; Xiang, L.; Song, H.; Zhang, C.; Yao, J.; Guo, H. Genesis of Megacrystalline Uraninite: A Case Study of the Haita Area of the Western Margin of the Yangtze Block, China. Minerals 2021, 11, 1173. https://doi.org/10.3390/ $\min 11111173$

Academic Editor: David Quirt

Received: 14 September 2021

Accepted: 20 October 2021

Published: 22 October 2021

Publisher's Note: MDPI stays neutral with regard to jurisdictional claims in published maps and institutional affiliations.

Copyright: (c) 2021 by the authors. Licensee MDPI, Basel, Switzerland. This article is an open access article distributed under the terms and conditions of the Creative Commons Attribution (CC BY) license (https:/ / creativecommons.org/licenses/by/ $4.0 /)$.

\begin{abstract}
Megacrystalline uraninite (up to one centimeter in size) represents one of the most important discoveries in uranium mineralogy in the western margin of the Yangtze Block and even in China in recent years. However, the genesis of megacrystalline uraninite remains controversial. In this study, the megacrystalline uraninite found in the felsic and quartz veins in the Haita area is examined for the first time. The study examined the geochemical characteristics of uraninite in the two veins and resulted in two primary findings. (1) The genesis of the uraninite was likely intrusive and was closely related to partial melting. (2) The quartz vein and feldspar vein are cogenetic and have a simple differentiation evolution relationship. Therefore, the partial melting of felsic materials during migmatization may be the most important mechanism of uranium mineralization in the study area. Furthermore, further simple fractional crystallization may be another important mechanism for the formation of megacrystalline uraninite. This study enriches the REE database of uraninite in uranium deposits worldwide, which is meaningful for studying the genesis of megacrystalline uraninite.
\end{abstract}

Keywords: megacrystalline uraninite; partial melting; genesis; REE

\section{Introduction}

Uraninite is commonly found in uranium deposits formed in a variety of geological environments. These include high-grade metamorphic conditions as well as plutonic, metasomatic, hydrothermal, and basin diagenetic environments. These deposits may also be found in volcanic to sedimentary and superficial environments [1-5]. They contain a variety of elements, such as $\mathrm{Th}^{4+}, \mathrm{REE}^{3+}$, and $\mathrm{Y}^{3+}$, substituting $\mathrm{U}^{4+}$ with eight-fold coordination [6,7]. Uraninites of different genesis have significant differences in their chemical composition [2], which are controlled by the respective forming conditions, such as temperature, pressure, fluid composition, and oxygen fugacity [8]. Th has low solubility in low- to intermediate-temperature fluid. High-temperature uraninite tends to have a higher Th content than low-temperature uraninite [7,9-11]. In addition, uraninite from different geological conditions also has distinct REE contents and distribution patterns. Consequently, the composition of uraninite (e.g., ¿REE, U/Th ratio, Y and Zr contents, and LREE/HREE ratio) is useful for investigating its genesis [7,12-17].

Uraninite crystals are commonly smaller than $1 \mathrm{~mm}$ and are widespread in felsic or alkaline igneous rocks as an accessory mineral. Therefore, there are few reports of megacrystalline uraninite [18]. Uranium occurrences containing megacrystalline layers have been discovered in several migmatites along the western margin of the Yangtze 
Block in Southwest China. The megacrystalline uraninite found in the quartz vein in 2015 has attracted wide attention from geologists [19-21]. Its most prominent feature is its large particle size (up to one centimeter in scale) and complete crystal form $[19,20]$. In 2021, our research team discovered a large number of megacrystalline uraninites in the felsic vein of the A19 uranium occurrences in the Haita area. These megacrystalline uraninites in different veins in the Haita area provide natural and advantageous conditions for conducting research on their genesis.

In the study area, the geochemical and fluid inclusion characteristics of uraninite-rich quartz/felsic veins have led to valuable insights into the petrological, chronological, and geochemical attributes of the migmatite. The studies by Chang [22] and Liu [23] suggest that the initial enrichment of uranium was completed during the process of migmatization, and the uraninite in the felsic vein and quartz vein were formed in the Neoproterozoic. Guo et al. [24] suggest that the high-temperature hydrothermal process during migmatization in the study area led to the occurrence of uranium enrichment events, and the superimposed transformation of a late medium-low-temperature hydrothermal environment was the key factor for the formation of megacrystalline uraninite. Yin et al. [25] showed that the formation of coarse-grained uraninite was closely related to the increase in oxygen fugacity by studying the geochemical characteristics of apatite intergrown with uraninite in the quartz vein. However, the genesis of uraninite remains controversial, including the formation temperature (high temperature [19,20], low temperature [24]); genetic types (hydrothermal $[19,26]$ and high differentiation evolution of magma $[20,25,27,28])$. In addition, there is controversy as to whether the ore-bearing quartz vein and felsic vein were formed by the same geological event $[22,24]$. These controversies seriously restrict the further understanding of regional uranium metallogenic events. Therefore, this study selected uraninite in the quartz vein and felsic vein as the object of geochemical testing and compared the test results with uraninite geochemical characteristics in typical uranium deposits worldwide. The origin of uraninite and other metallogenic information is discussed by comparing the uraninite geochemical characteristics in different ore-bearing veins, the internal relationship between the quartz vein and felsic vein, the relationship between these veins and nearby rock masses, and by collecting the Hf content of zircon in different veins. Based on the results, the genesis of uraninite is determined and is discussed. This study is also helpful for the geological exploration of uranium deposits in the region.

\section{Geological Background}

\subsection{Regional Geological Background}

The western margin of the Yangtze Block is located in Southwest China (Figure 1a), an area with complex geological structures, diverse rock associations, and abundant ore resources [29-31]. Proterozoic to Quaternary rocks are variably exposed in the area and Precambrian rocks are common (Figure 1b). Magmatic rocks include ultramafic, mafic, acidic to alkaline, and intrusive to volcanic rocks that were formed from the Proterozoic to Mesozoic. In particular, many mafic to acidic intrusive rocks that formed during the Jinning period (800 Ma to $1000 \mathrm{Ma}$ ) are widespread along the NS-trending structural belt.

\subsection{Geological Background of the Study Area}

The study area is in the southwest portion of Miyi County, an area that has experienced extensive metamorphism and migmatization (Figure 1c). The strata in the area mainly comprise Proterozoic medium- to high-grade metamorphic rocks of the Wumaqing Group and Sinian-Cambrian carbonate and clastic rocks of the Dengying Formation. Multistage magmatism is widespread in this area. Magmatic rocks are dominated by Jinningian intermediate to felsic rocks and Hercynian-Indochina alkaline rocks. The study area is also characterized by extensive folding and shear zones involving brittle and ductile faults, such as the NS-oriented Mopan Mountain and Anning River faults. Although most rocks in the area have experienced significant deformation and metamorphism, the original structure was variably eliminated by substantial surface weathering processes. 
The host rocks of the uranium ore body are migmatites of the Proterozoic Wumaqing Formation, which formed during the Neoproterozoic. The leucosomes and melanosomes of the migmatites have sharp boundaries. The melanosome is mainly composed of micaquartz schist/gneiss. The leucosome mainly comprises quartz, plagioclase, and potassium feldspar, with minor uraninite, apatite, sphene, and sulfide. Three uranium occurrences (A10, A19, and 2811) were discovered in this area. Uraninite at A10 and A19 occurs in felsic veins composed of feldspar and quartz, while the leucosome in 2811 contains $>80 \%$ quartz and was regarded as a quartz vein.

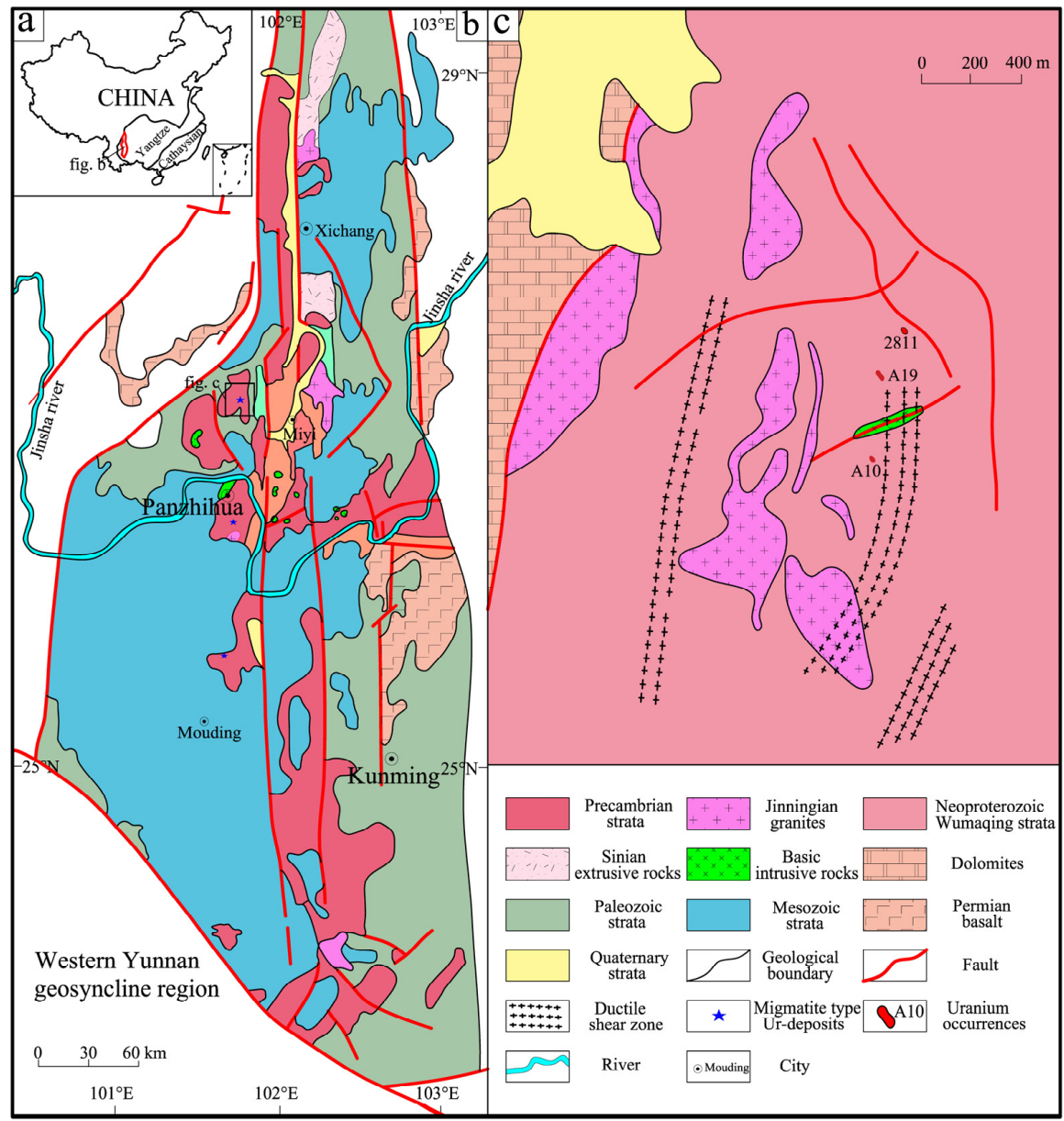

Figure 1. (a) Location of the Kangdian region in China, (b) geological map of the Kangdian region, and (c) geological map of the Haita area (modified after Wang et al. [20]).

\subsection{Geology of Uranium Occurrences}

The uraninite-rich felsic vein is emplaced in the plagioclase gneiss along the schistosity (Figure 2a). More euhedral dark minerals (pyroxene and hornblende) are found in the felsic vein (Figure 2c,d), which may have formed by wall-rock alteration. Uraninite (UrA) intergrown with dark minerals has the characteristics of large particle size but subhedral crystal shape (Figure 2e). Uraninite (UrB), which is intergrown with quartz and feldspar (Figure 2f,g,h), is characterized by a nearly euhedral crystal shape with a smaller particle size. The main accessory minerals are sphene, apatite, zircon, molybdenite, and pyrite (Figure 2b,d,h).

The uraninite-bearing quartz vein occurs as a lens hosted by plagioclase gneiss (Figure 3a). It is up to $35-50 \mathrm{~cm}$ wide and nearly parallel to the gneissic schistosity. Hundreds of euhedral uraninite grains up to several centimeters in size were observed in the vein (Figure $3 b)$. Euhedral sphenes were commonly enclosed in uraninite $(\mathrm{UrC})$ 
(Figure 3d). The coexisting accessory minerals were quartz, apatite, zircon, molybdenite, pyrite, and minor feldspar (Figure 3c,e).

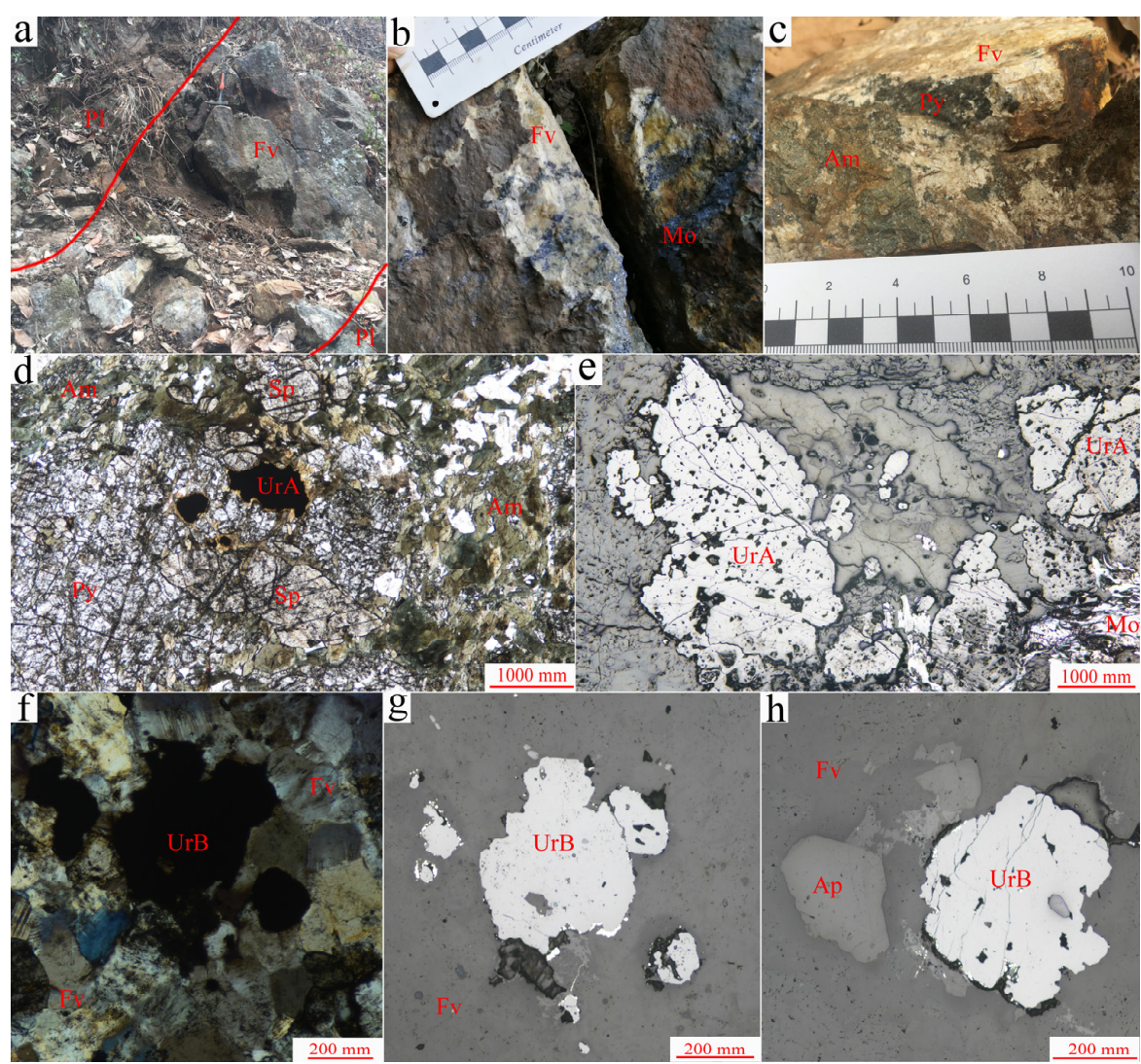

Figure 2. (a) Felsic vein (Fv), (b) Molybdenite in felsic vein, (c) Dark idiomorphic mineral in felsic vein, (d) Uraninite in dark idiomorphic mineral, (e) Megacrystalline uraninite in dark idiomorphic mineral, and (f-h) Megacrystalline uraninite in felsic vein. Abbreviations: Pl, Plagioclase gneiss; Mo, Molybdenite; Py, Pyroxene; Am, Amphibole; Ap, Apatite; Sp, Sphene.

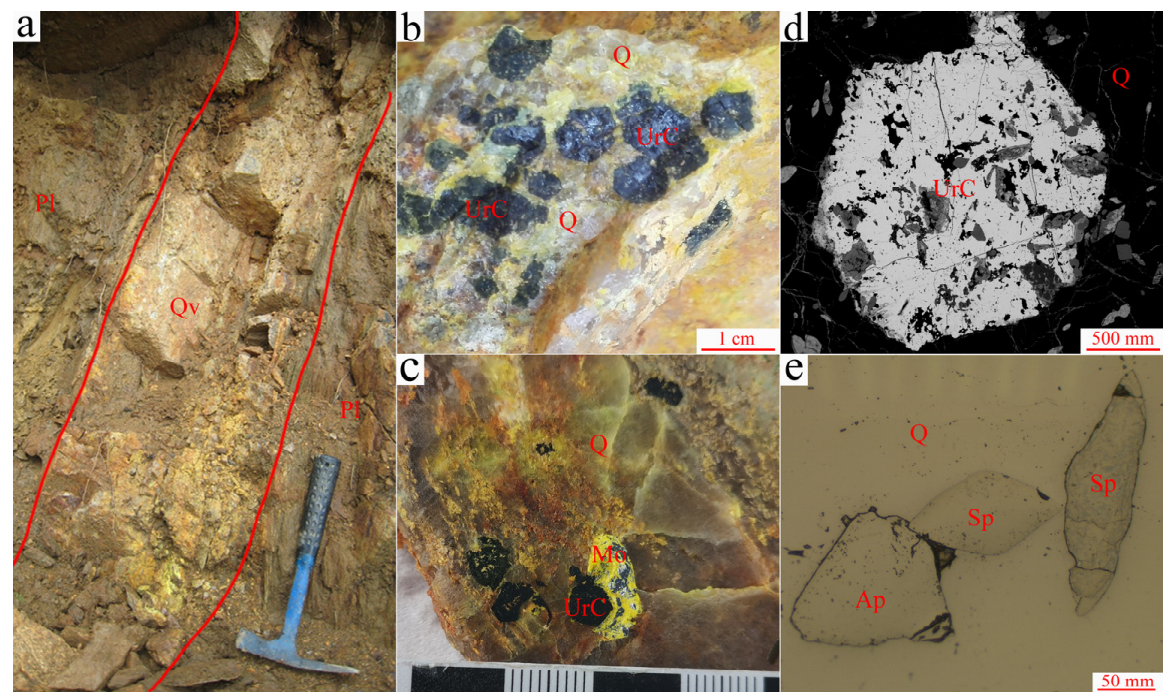

Figure 3. (a) Quartz vein (Qv), (b,c) Megacrystalline uraninite in quartz vein, (d) BSE of megacrystalline uraninite, (e) Apatite and sphene in quartz vein. 


\section{Analytical Methods}

In this study, six specimens of uraninite-rich felsic vein (Figure 2a) and three hand specimens of uraninite-rich quartz vein (Figure 3a) were collected from the A19 and 2811 uranium occurrences. The samples were preprocessed in the Geochemistry Department at Chengdu University of Technology (CDUT). Thin sections of samples of the quartz vein (No. 2811) and felsic vein (No. A19) were prepared for optical microscopy study and microprobe analysis. Through the detailed rock and ore identification work, the uraninite which was symbiotic with dark minerals and the uraninite which was symbiotic with quartz and feldspar in felsic vein were selected, respectively, and the uraninite occurring in quartz vein was selected for testing. Whereas rock and mineral identification was performed in the Comprehensive Rock and Mineral Identification Laboratory at CDUT using a Nikon LV100 POL polarizing microscope.

Major element $(\mathrm{U}, \mathrm{Th}, \mathrm{Pb})$ analyses were conducted using an electron probe microanalyzer (EPMA-1600) at the Tianjin Center of the Geological Survey of China. Tests were conducted using the following settings: an accelerating voltage of $15.0 \mathrm{kV}$, a beam current of $20.0 \mathrm{nA}$, and a beam spot diameter of $1 \mu \mathrm{m}$, with a ZAF calibration mode and operational procedures performed based on the GB/T 15617-2002 standard. The standard sample used in the test process was the SPI standard sample group from the United States, and the test accuracy was better than $2 \%$. The SPI standard sample contains 53 selected minerals, each of which has a high degree of homogeneity within and between crystal grains, and has stable performance in a vacuum, atmospheric environment and electron beams. When measuring the trace element concentrations in the same position, glass reference standards, including SRM610, BHVO-2G, BCR-2G, and IR-1G, were used as the external standard samples. An SRM610 standard sample was clamped with seven sample points, and ${ }^{238} \mathrm{U}$ was used as the internal standard element for the correction of trace elements. The timeresolved analyses data included an approximately $20 \mathrm{~s}$ blank signal and $50 \mathrm{~s}$ sample signal. The ICPMS-DATACAL software was employed for offline data processing [32,33].

\section{Geochemical Composition of Uraninite}

In total, 33 points were analyzed. These included 20 uraninite grains from the felsic vein (10 grains each from $\mathrm{UrA}$ and $\mathrm{UrB}$ ) and $13 \mathrm{UrC}$ grains from the quartz vein.

\subsection{Major Element Compositions}

The contents of major elements of UrA in the felsic vein were as follows (Table 1): $\mathrm{UO}_{2}$ was $88.50-89.91 \%$ (mean $=89.11 \%$ ), $\mathrm{ThO}_{2}$ was $2.94-3.87 \%$ (mean $=3.49 \%$ ), and $\mathrm{PbO}_{2}$ was $2.82-3.10 \%$ (mean $=2.95 \%$ ). The UrB elements in the felsic vein were as follows: $\mathrm{UO}_{2}$ was $88.75-89.94 \%$ (mean $=89.25 \%$ ), $\mathrm{ThO}_{2}$ was $2.37-3.19 \%$ (mean $=2.77 \%$ ), and $\mathrm{PbO}_{2}$ was $2.65-2.94 \%$ (mean $=2.83 \%$ ). The contents of major elements of $\mathrm{UrC}$ in the quartz vein were as follows: $\mathrm{UO}_{2}$ was $84.40-86.01 \%$ (mean $\left.=85.13 \%\right), \mathrm{ThO}_{2}$ was $4.68-6.15 \%$ (mean $=5.34 \%$ ), and $\mathrm{PbO}_{2}$ was $2.81-3.24 \%$ (mean $=3.03 \%$ ). In addition, the uraninite tested in this study contained lesser amounts of $\mathrm{Ca}, \mathrm{Fe}, \mathrm{Ti}, \mathrm{Si}$, and other elements.

\subsection{Trace Element Compositions}

The test data are shown in Table 2. $\sum$ REE of UrA was 9625.94-21,224.89 ppm $($ mean $=17,379.98 \mathrm{ppm}),(\mathrm{La} / \mathrm{Yb})_{\mathrm{N}}=0.01-0.13($ mean $=0.05) . \sum R E E$ of UrA had an obvious negative Eu anomaly $(\delta \mathrm{Eu}=0.23-0.40$, mean $=0.31)$. $\sum \mathrm{REE}$ of $\mathrm{UrB}$ was $15,213.27-18,141.44 \mathrm{ppm}$ (mean $=17,034.62 \mathrm{ppm}$ ), and the difference of light REE (LREE) and heavy REE (HREE) was clear $(\mathrm{La} / \mathrm{Yb})_{\mathrm{N}}=0.08-0.14$ (mean $\left.=0.11\right)$, with an obvious negative Eu anomaly $(\delta \mathrm{Eu}=0.36-0.42$, mean $=0.39)$. The $\sum \mathrm{REE}$ of UrC was $12,114.26-15,279.34 \mathrm{ppm}$ (mean $=13,600.93 \mathrm{ppm})$ and the difference of LREE and HREE was obvious $(\mathrm{La} / \mathrm{Yb})$ $\mathrm{N}=0.10-0.12$ (mean $=0.11)$, with an obvious negative Eu anomaly $(\delta \mathrm{Eu}=0.35-0.37$, mean $=0.37$ ). In the REE distribution curve (Figure 4e), UrA and UrB in the felsic vein and $\mathrm{UrC}$ in the quartz vein show relatively flat distribution patterns with high total amounts, 
while the obvious negative Eu anomaly may be related to plagioclase minerals in the source region.

In addition, $\mathrm{UrA}$ and $\mathrm{UrB}$ in the felsic vein and $\mathrm{UrC}$ in the quartz vein have high concentrations of $\mathrm{Zr}$ and $\mathrm{Y}$. $\mathrm{Zr}$ content in UrA was 78.17-163.70 ppm (mean $=107.58 \mathrm{ppm}$ ) and in UrB was 98.91-166.89 ppm (mean $=133.88 \mathrm{ppm}$ ). The $\mathrm{Zr}$ content in UrC was $101.05-213.52 \mathrm{ppm}(\mathrm{mean}=149.02 \mathrm{ppm})$. The $Y$ content in UrA was $6571.92-15164.90 \mathrm{ppm}$ $($ mean $=12,087.72 \mathrm{ppm})$ and the $\mathrm{Y}$ content in UrB was 9027.06-11,348.09 ppm $($ mean $=10,626.93 \mathrm{ppm})$. The $Y$ content in $\mathrm{UrC}$ was $7706.36-10,141.08 \mathrm{ppm}$ (mean $=8813.00 \mathrm{ppm})$.

Table 1. Oxide concentrations (wt \%) of megacrystalline uraninite.

\begin{tabular}{|c|c|c|c|c|c|c|c|c|c|c|c|c|}
\hline NO. & $\mathrm{Na}_{2} \mathrm{O}$ & $\mathrm{MgO}$ & $\mathrm{Al}_{2} \mathrm{O}_{3}$ & $\mathrm{SiO}_{2}$ & $\mathrm{PbO}$ & $\mathrm{ThO}_{2}$ & $\mathrm{UO}_{2}$ & $\mathrm{~K}_{2} \mathrm{O}$ & $\mathrm{CaO}$ & $\mathrm{TiO}_{2}$ & $\mathrm{FeO}$ & Total \\
\hline UrA1 & / & 0.013 & I & 0.012 & 2.759 & 2.722 & 88.747 & 0.159 & 0.233 & 0.036 & 0.080 & 94.761 \\
\hline UrA2 & 0.014 & 0.002 & / & 0.02 & 2.877 & 3.164 & 89.067 & 0.161 & 0.272 & 0.030 & / & 95.607 \\
\hline UrA3 & / & / & / & 0.038 & 2.759 & 3.007 & 89.940 & 0.151 & 0.277 & 0.014 & 0.065 & 96.251 \\
\hline UrA4 & 0.009 & / & / & 0.020 & 2.773 & 3.189 & 89.186 & 0.156 & 0.238 & 0.073 & 0.033 & 95.677 \\
\hline UrA5 & 0.022 & / & / & 0.015 & 2.939 & 2.671 & 89.327 & 0.148 & 0.254 & 0.019 & / & 95.395 \\
\hline UrA6 & / & / & / & 0.018 & 2.853 & 2.653 & 88.993 & 0.162 & 0.244 & 0.005 & / & 94.928 \\
\hline UrA7 & 0.006 & 0.006 & / & 0.022 & 2.905 & 2.555 & 89.890 & 0.162 & 0.261 & 0.006 & 0.029 & 95.842 \\
\hline UrA8 & / & / & I & 0.022 & 2.93 & 2.912 & 88.861 & 0.15 & 0.235 & 0.049 & 0.027 & 95.186 \\
\hline UrA9 & 0.002 & / & / & 0.028 & 2.833 & 2.37 & 89.091 & 0.145 & 0.151 & 0.062 & 0.172 & 94.854 \\
\hline UrA10 & 0.005 & 0.01 & I & 0.622 & 2.652 & 2.498 & 89.433 & 0.165 & 0.305 & 0.009 & 0.074 & 95.773 \\
\hline UrB1 & 0.003 & 0.017 & I & 0.022 & 3.056 & 3.427 & 88.496 & 0.159 & 0.331 & 0.039 & / & 95.55 \\
\hline UrB2 & 0.022 & 0.019 & / & 0.019 & 2.976 & 2.938 & 89.909 & 0.161 & 0.354 & 0.083 & / & 96.481 \\
\hline UrB3 & 0.029 & 0.004 & I & 0.035 & 3.096 & 3.335 & 89.387 & 0.139 & 0.316 & 0.037 & / & 96.378 \\
\hline UrB4 & 0.003 & 0.015 & / & 0.035 & 2.945 & 3.455 & 89.397 & 0.174 & 0.377 & 0.001 & / & 96.402 \\
\hline UrB5 & 0.01 & 0.018 & I & 0.053 & 2.818 & 3.412 & 88.985 & 0.169 & 0.354 & 0.022 & / & 95.841 \\
\hline UrB6 & 0.001 & 0.005 & 0.008 & 0.720 & 2.851 & 3.420 & 88.957 & 0.178 & 0.304 & 0.049 & 0.050 & 96.543 \\
\hline UrB7 & / & 0.003 & / & 0.035 & 2.969 & 3.870 & 89.051 & 0.156 & 0.312 & 0.055 & 0.040 & 96.491 \\
\hline UrB8 & 0.026 & 0.011 & / & 0.026 & 2.961 & 3.638 & 89.437 & 0.167 & 0.260 & 0.052 & 0.007 & 96.585 \\
\hline UrB9 & / & 0.023 & I & 0.040 & 2.853 & 3.570 & 88.683 & 0.166 & 0.402 & 0.033 & / & 95.77 \\
\hline UrB10 & / & 0.005 & / & 0.001 & 2.938 & 3.841 & 88.845 & 0.152 & 0.334 & 0.061 & / & 96.177 \\
\hline UrC1 & 0.02 & 0.004 & / & 0.060 & 3.238 & 4.679 & 84.996 & 0.252 & 0.301 & 0.027 & / & 93.577 \\
\hline $\mathrm{UrC} 2$ & 0.005 & 0.005 & 0.046 & 0.050 & 2.976 & 4.726 & 84.440 & 0.229 & 0.414 & 0.014 & 0.034 & 92.939 \\
\hline $\mathrm{UrC3}$ & 0.004 & / & / & 0.017 & 2.806 & 5.217 & 85.583 & 0.171 & 0.369 & 0.082 & 0.047 & 94.296 \\
\hline UrC4 & 0.012 & 0.013 & I & 0.070 & 2.938 & 5.233 & 85.552 & 0.211 & 0.350 & 0.059 & / & 94.438 \\
\hline UrC5 & 0.007 & / & / & 0.084 & 2.994 & 6.147 & 84.396 & 0.185 & 0.262 & 0.043 & / & 94.118 \\
\hline UrC6 & / & / & / & 0.095 & 3.031 & 5.672 & 84.589 & 0.227 & 0.313 & 0.026 & 0.018 & 93.971 \\
\hline UrC7 & / & 0.011 & I & 0.095 & 3.063 & 5.639 & 84.758 & 0.191 & 0.482 & 0.015 & 0.064 & 94.318 \\
\hline UrC8 & 0.009 & / & / & 0.045 & 3.224 & 5.261 & 85.439 & 0.205 & 0.279 & 0.028 & 0.010 & 94.500 \\
\hline UrC9 & 0.017 & 0.009 & / & 0.070 & 3.051 & 4.977 & 85.828 & 0.239 & 0.413 & 0.014 & / & 94.618 \\
\hline UrC10 & 0.009 & / & 0.816 & 0.156 & 3.093 & 5.247 & 84.815 & 0.170 & 0.490 & 0.028 & 0.004 & 94.828 \\
\hline UrC11 & 0.013 & / & / & 0.062 & 3.095 & 5.399 & 86.066 & 0.207 & 0.344 & 0.029 & 0.002 & 95.217 \\
\hline UrC12 & 0.006 & 0.016 & 0.032 & 0.061 & 2.857 & 5.429 & 85.165 & 0.205 & 0.463 & 0.044 & / & 94.278 \\
\hline UrC13 & 0.022 & / & / & 0.067 & 2.998 & 5.772 & 85.125 & 0.200 & 0.324 & 0.050 & 1 & 94.558 \\
\hline
\end{tabular}


Table 2. Trace element composition of megacrystalline uraninite.

\begin{tabular}{|c|c|c|c|c|c|c|c|c|c|c|c|c|c|c|c|c|c|c|}
\hline NO. & $\mathbf{V}$ & $\mathbf{Y}$ & $\mathrm{Zr}$ & La & $\mathrm{Ce}$ & Pr & Nd & Sm & Eu & Gd & $\mathrm{Tb}$ & Dy & Ho & Er & $\mathrm{Tm}$ & $\mathrm{Yb}$ & $\mathbf{L u}$ & Hf \\
\hline UrA1 & 3.78 & $13,361.93$ & 122.12 & 81.36 & 1925.00 & 528.19 & 3599.89 & 1934.33 & 179.20 & 2193.33 & 402.89 & 2987.46 & 694.52 & 1996.01 & 295.10 & 1963.88 & 218.99 & 0.49 \\
\hline UrA2 & 2.53 & $10,847.38$ & 95.59 & 25.63 & 1220.05 & 400.80 & 2922.62 & 1566.42 & 154.02 & 1797.94 & 323.29 & 2336.55 & 560.95 & 1607.01 & 230.82 & 1572.98 & 179.02 & 0.33 \\
\hline UrA3 & 2.60 & 6751.92 & 91.55 & 16.89 & 789.21 & 262.58 & 2048.07 & 1012.02 & 139.45 & 1133.26 & 199.62 & 1430.58 & 335.83 & 983.84 & 143.71 & 1007.52 & 123.36 & 0.24 \\
\hline UrA5 & 3.20 & $14,364.34$ & 85.57 & 35.02 & 1516.55 & 473.73 & 3454.72 & 1838.54 & 177.63 & 2206.75 & 427.65 & 3150.71 & 721.65 & 2143.83 & 310.74 & 2125.68 & 238.39 & 0.41 \\
\hline UrA6 & 3.91 & $12,002.10$ & 163.70 & 309.63 & 4238.08 & 844.89 & 4595.41 & 1773.90 & 185.18 & 1898.67 & 353.99 & 2502.39 & 593.11 & 1722.55 & 252.00 & 1757.59 & 197.49 & 0.74 \\
\hline UrA7 & 5.06 & $12,322.04$ & 158.78 & 313.81 & 4007.86 & 796.15 & 4512.94 & 1745.23 & 186.17 & 1985.75 & 363.67 & 2543.86 & 608.03 & 1771.57 & 252.68 & 1784.60 & 199.93 & 0.90 \\
\hline UrA8 & 4.03 & $15,164.90$ & 94.15 & 26.69 & 1394.84 & 435.16 & 3316.43 & 1942.52 & 164.84 & 2376.74 & 446.57 & 3331.00 & 778.19 & 2287.38 & 329.25 & 2234.14 & 244.75 & 0.44 \\
\hline UrA10 & 4.74 & $12,379.11$ & 96.66 & 127.28 & 2365.67 & 554.79 & 3631.23 & 1656.62 & 182.74 & 1876.94 & 353.86 & 2551.39 & 610.82 & 1767.58 & 263.67 & 1780.48 & 209.41 & 0.53 \\
\hline UrB1 & 0.11 & $11,043.63$ & 104.01 & 218.24 & 2510.62 & 551.69 & 3389.77 & 1538.18 & 165.82 & 1805.19 & 333.18 & 2440.02 & 572.39 & 1695.01 & 243.00 & 1660.22 & 189.75 & 0.76 \\
\hline UrB2 & 0.05 & $10,707.16$ & 98.91 & 186.84 & 2490.20 & 544.70 & 3246.34 & 1484.17 & 214.83 & 1736.41 & 325.25 & 2396.59 & 565.28 & 1672.90 & 237.94 & 1636.68 & 190.85 & 1.11 \\
\hline UrB3 & 0.10 & $11,348.09$ & 147.70 & 259.27 & 2903.89 & 598.11 & 3463.29 & 1571.05 & 200.65 & 1832.11 & 339.11 & 2455.77 & 593.48 & 1718.50 & 246.80 & 1688.02 & 194.60 & 1.49 \\
\hline UrB4 & 0.04 & $11,275.54$ & 152.07 & 256.06 & 2887.86 & 609.73 & 3528.70 & 1590.68 & 211.82 & 1818.41 & 332.57 & 2484.59 & 578.35 & 1715.22 & 244.23 & 1686.15 & 197.06 & 1.30 \\
\hline UrB5 & 0.02 & $11,098.00$ & 151.00 & 256.66 & 2869.11 & 590.55 & 3487.95 & 1552.83 & 199.32 & 1761.91 & 330.95 & 2448.63 & 572.09 & 1670.86 & 243.02 & 1641.45 & 196.16 & 1.13 \\
\hline UrB6 & 0.51 & 9677.55 & 138.54 & 169.79 & 2331.16 & 506.77 & 3010.07 & 1362.88 & 197.42 & 1532.27 & 281.97 & 2072.87 & 494.05 & 142 & 207.68 & 147 & 172.37 & 0.61 \\
\hline UrB7 & 0.37 & $10,448.28$ & 166.89 & 316.64 & 3063.05 & 626.92 & 3462.49 & 1510.98 & 203.16 & 1691 & & 2302.84 & 538 & & 229.24 & & 184.33 & 1.61 \\
\hline UrB8 & 0.20 & 11,1 & 132.13 & 248.35 & 2694.28 & 569.86 & 331 & 1534.65 & 216.13 & & & & & & & & 197.76 & 1.12 \\
\hline UrB10 & 0.34 & $10,494.09$ & 126.37 & 201.13 & 2536.71 & 535.48 & 3160.21 & 1484.23 & 192.73 & 1675.22 & 311.15 & 2328.38 & 534.05 & 1592.50 & 231.82 & 1585.89 & 181.08 & 0.79 \\
\hline UrC1 & 1.54 & 7706.36 & 141.83 & 174.92 & 2016.67 & 411.08 & 2406.91 & 1013.54 & 133.53 & 1136.31 & 207.01 & 1537.51 & 383.49 & 1161.50 & 170.34 & 1217.54 & 143.90 & 0.57 \\
\hline UrC2 & 0.47 & 8471.67 & 115.06 & 210.35 & 2164.55 & 432.97 & 2483.67 & 1080.87 & 140.75 & 1228.42 & 223.12 & 1674.94 & 426.69 & 1299.89 & 191.19 & 1360.06 & 163.98 & 0.48 \\
\hline UrC3 & 1.89 & 8948.43 & 114.58 & 193.72 & 2202.64 & 448.04 & 2626.37 & 1110.83 & 145.92 & 1267.47 & 232.85 & 1736.58 & 442.23 & 1334.32 & 196.45 & 1391.19 & 169.38 & 0.57 \\
\hline $\mathrm{UrC} 4$ & 0.34 & 8742.42 & 175.81 & 191.47 & 2188.19 & 445.13 & 2574.38 & 1099.36 & 143.38 & 1261.68 & 228.98 & 1718.85 & 436.62 & 1333.54 & 195.69 & 1396.17 & 168.93 & 0.91 \\
\hline UrC5 & 0.78 & 8587.08 & 110.09 & 210.68 & 2394.16 & 464.08 & 2641.75 & 1083.51 & 137.43 & 1230.43 & 220.66 & 1662.78 & 419.98 & 1302.81 & 191.55 & 1385.97 & 166.14 & 0.57 \\
\hline UrC6 & 0.47 & 8347.09 & 101.05 & 209.24 & 2261.53 & 440.70 & 2477.16 & 1028.83 & 133.01 & 1189.24 & 218.17 & 1604.92 & 411.60 & 1261.34 & 187.82 & 1361.88 & 167.02 & 0.42 \\
\hline UrC7 & 0.79 & 9278.59 & 141.05 & 255.57 & 2420.54 & 476.92 & 2729.45 & 1153.95 & 149.84 & 1333.76 & 245.77 & 1803.37 & 462.93 & 1431.22 & 209.96 & 149 & 183.35 & 0.81 \\
\hline UrC8 & 0.45 & 9266.14 & 213.52 & 205.00 & 2303.11 & 466.39 & 2698.70 & 1152.92 & 144.48 & 1305.24 & 236.98 & 1795.78 & 458.58 & 1434.80 & 211.44 & 1543.30 & 186.75 & 0.87 \\
\hline $\mathrm{UrC} 9$ & 2.38 & 7884.69 & 163.64 & 179.95 & 2079.02 & 425.71 & 2388.00 & 1035.53 & 137.54 & 1162.74 & 210.41 & 1558.65 & 400.04 & 1222.28 & 176.10 & 1265.46 & 150.88 & 0.64 \\
\hline UrC10 & 5.57 & 9634.39 & 194.74 & 241.43 & 2499.32 & 487.35 & 2745.06 & 1143.07 & 153.87 & 1331.84 & 246.47 & 1853.03 & 474.07 & 1477.31 & 213.45 & 1546.54 & 189.30 & 1.11 \\
\hline UrC11 & 0.15 & 9114.62 & 186.27 & 220.14 & 2356.95 & 477.90 & 2712.03 & 1136.25 & 140.57 & 1311.25 & 239.59 & 1778.94 & 458.05 & 1411.81 & 208.65 & 1499.53 & 182.50 & 0.60 \\
\hline $\mathrm{UrC} 12$ & 0.83 & $10,141.08$ & 156.43 & 254.57 & 2621.67 & 511.55 & 2875.30 & 1227.34 & 169.02 & 1437.10 & 258.98 & 1952.98 & 485.20 & 1517.44 & 218.37 & 1563.90 & 185.90 & 0.62 \\
\hline $\mathrm{UrC13}$ & 0.67 & 8446.43 & 123.17 & 208.92 & 2328.10 & 459.82 & 2564.20 & 1079.40 & 134.62 & 1249.46 & 224.93 & 1686.31 & 424.54 & 1296.42 & 189.51 & 1364.84 & 162.39 & 0.64 \\
\hline
\end{tabular}

Note: content unit is ppm. 


\section{Discussion}

\subsection{Comparison of Genetic Type}

Uraninite occurring at different temperatures and environments has specific rare earth element (REE) contents and patterns [17,34]. At medium to low temperatures $\left(<350^{\circ} \mathrm{C}\right)$ uraninite has a low REE content and a strongly fractionated REE pattern owing to the crystallographic control of the mineral structure. It demonstrates a preferential incorporation of $\mathrm{Tb}, \mathrm{Dy}, \mathrm{Ho}$, and Er that have similar ionic radii to $\mathrm{U}^{4+}$, leading to "bell shape" REE patterns. At a temperature of $>350{ }^{\circ} \mathrm{C}$, the dilatational nature of the uraninite structure allows the incorporation of large amounts of REEs without fractionation ( $\Sigma$ LREE/ $/$ HREE $\approx 1$, intrusive and synmetamorphic deposits), resulting in "flat" REE patterns and a strong negative Eu anomaly reflecting early fractionation of plagioclase in the silicate melt for intrusive deposits. Therefore, the degree of fractionation and REE content are important criteria for indicating temperature of uraninite crystallization and thus the genetic environment of formation. The results of this test show that all uraninite had a higher total amount of REEs and relatively flat seagull-type REE distribution patterns. The fractionation of REEs during the formation of the studied uraninite is not obvious, indicating that it was formed in a high-temperature environment. Mercadier et al. [17] systematically summarized the REE distribution patterns of uranium minerals in typical intrusive, synmetamorphic, unconformity-related, vein-type, roll-front, and volcanic-related uranium deposits worldwide (Figure 4a-d). Uraninite in the study area was compared with the REE distribution patterns of uraninite in typical uranium deposits worldwide and found to be consistent with REE distribution patterns of uranium minerals in intrusive (pegmatite) uranium deposits (Figure 4a,e). In the REE and LREE/HREE diagrams (Figure 4f), the uraninite in the study area is plotted in the field of intrusive (pegmatite) uranium deposits.

Based on the research results of Mercadier et al. [17] and Frimmel et al. [7], the U/Th ratio, $\sum \mathrm{REE}$, and uraninite distribution patterns can be used to roughly reflect the oreforming temperature and genetic environment. The concentrations of trace elements such as $\mathrm{Zr}$ and $\mathrm{Y}$ can be used to indicate the genesis of uraninite.

(1) The U/Th ratio of uraninite varies greatly depending on the crystallization temperature. All examples of low-temperature hydrothermal uraninite do not contain Th $(\mathrm{U} / \mathrm{Th}>1000)$, while those formed at higher temperatures $\left(>450^{\circ} \mathrm{C}\right)$ usually have a higher $\mathrm{ThO}_{2}$ content $(\mathrm{U} / \mathrm{Th}<100)$.

(2) Because $Y$ and REE have the same geochemical properties, the $Y$ and REE contents are usually positively correlated. Additionally, the higher the temperature, the stronger is the isomorphism. Therefore, the REE and Y concentrations will greatly increase under high-temperature conditions.

(3) The $\mathrm{Zr}$ content in all low-temperature hydrothermal uraninite is very low; usually not more than a few ppm.

In this study, the U/Th ratios of UrA, UrB, and UrC were all $<100$ in the Th and $\mathrm{U}$ concentration diagrams (Figure 5a). Owing to the increase in Th content in UrC, the $\mathrm{U} / \mathrm{Th}$ ratio of $\mathrm{UrC}$ was lower than that of UrA and UrB. Therefore, we suggest that all uraninite examined in this study formed at a high temperature. $\mathrm{UrA}, \mathrm{UrB}$, and $\mathrm{UrC}$ have relatively uniform REE and $Y$ contents. REE and $Y$ concentrations show a significant positive correlation, and all the data plotted in the field of magmatic deposits on the REE vs. $\mathrm{Y}$ diagram (Figure $5 \mathrm{~b}$ ). UrA, UrB, and UrC have relatively stable and high concentrations of $\mathrm{Zr}$, which is similar to the intrusive (pegmatite) Ekomedion deposit (Figure 6a).

The above features indicate that the uraninite from the quartz and felsic veins in the study area originated from intrusive rock. We suggest that such uranium mineralization be classified into the subtype of Pegmatite-Alaskite [4] according to the IEAE (International Atomic Energy Agency) classification. This type of uraninite is formed by partial melting in high-temperature and low-pressure environments. 

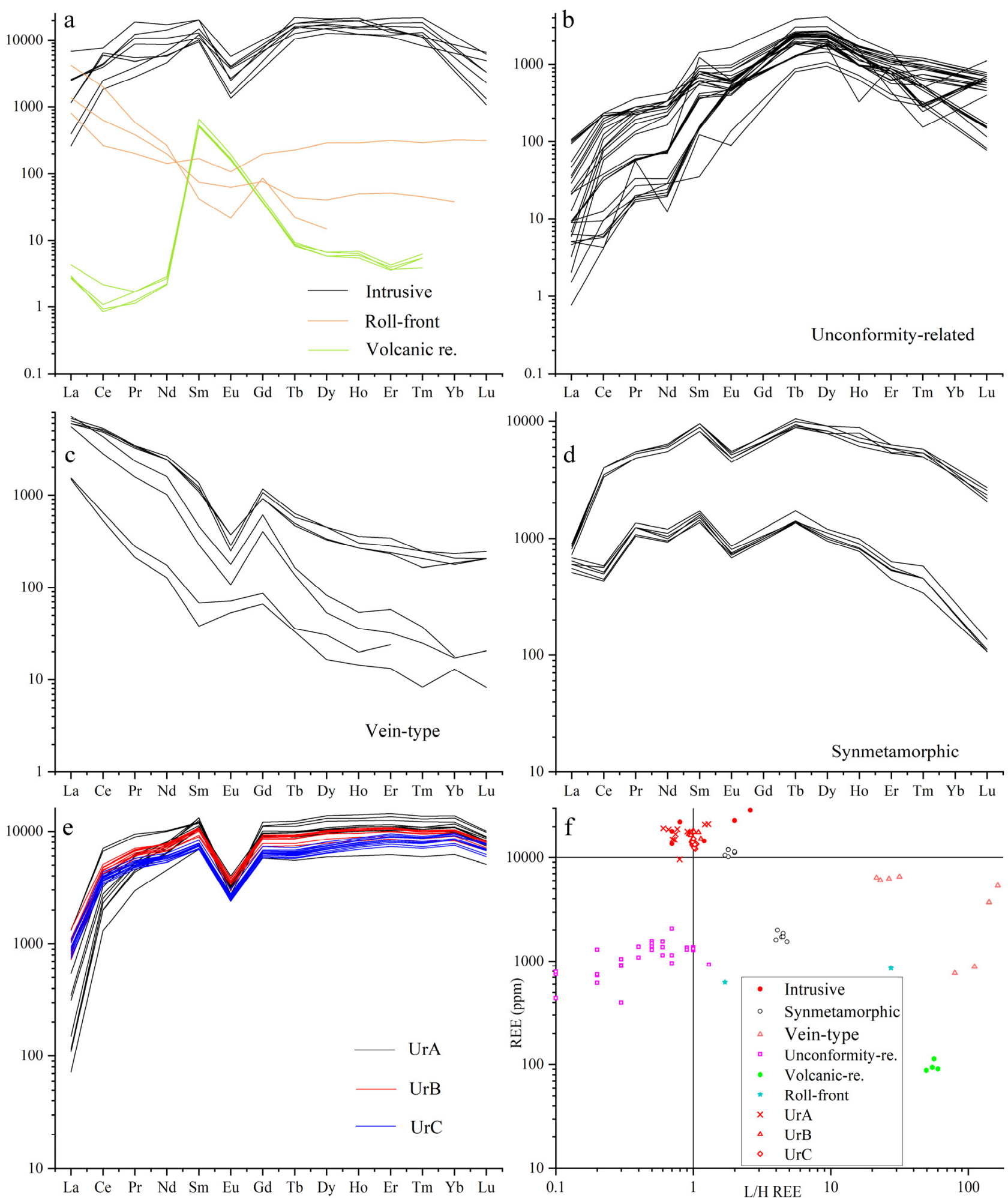

Figure 4. (a-d) Chondrite-normalised rare earth element patterns for uranium oxides from six different types of uranium occurrences (data from Mercadier et al. [17]), (e) Chondrite-normalized rare earth element patterns of UrA/UrB/UrC (Chondrite values are from Anders and Grevesse [35]), and (f) Rare earth element abundance ( $\Sigma$ REE) vs. REE fractionation $((\Sigma$ LREE/ $/$ HREE) N) from six different types of uranium occurrences and UrA/UrB/UrC 

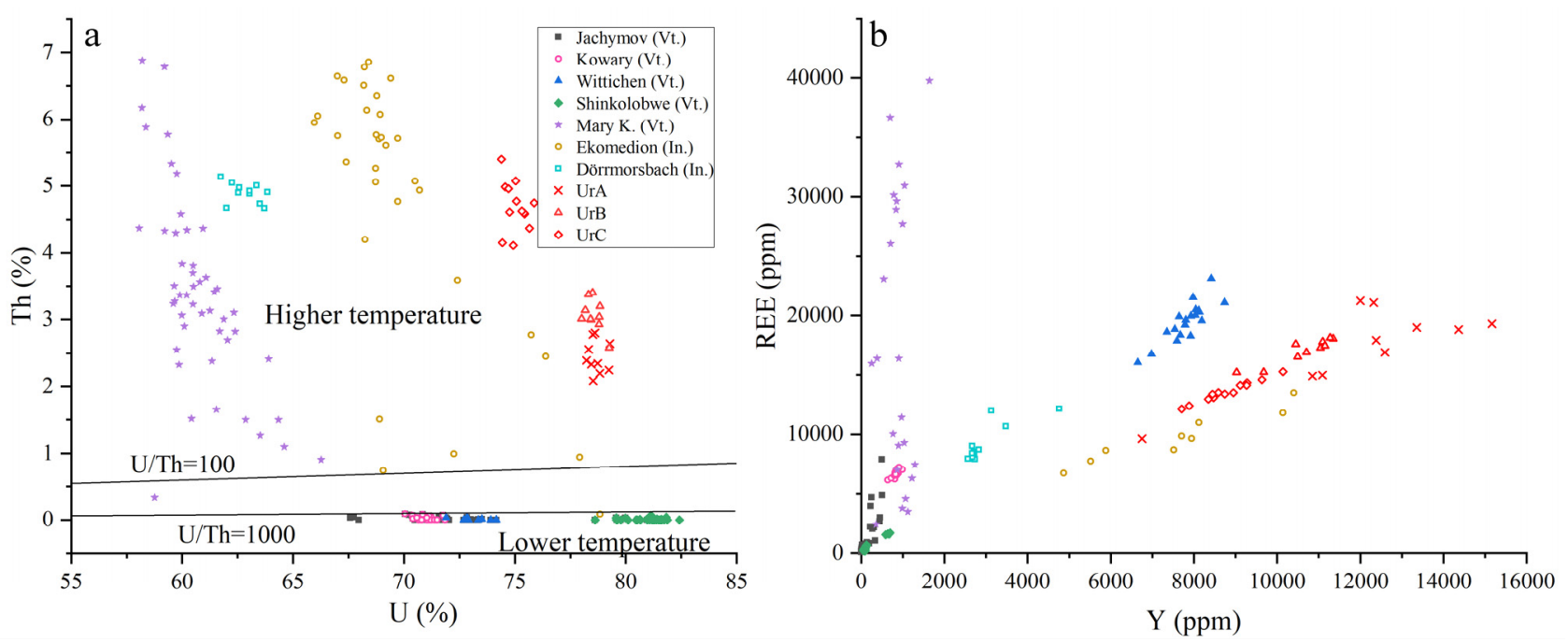

Figure 5. (a) Th versus $U$ content in uraninite from various types of deposits and UrA/UrB/UrC, and (b) REE versus $\mathrm{Y}$ content in uraninite from various types of deposits and UrA/UrB/UrC (data from Frimmel et al. [7] and this study). Abbreviations: Vt., Vein-type; In., Intrusive.
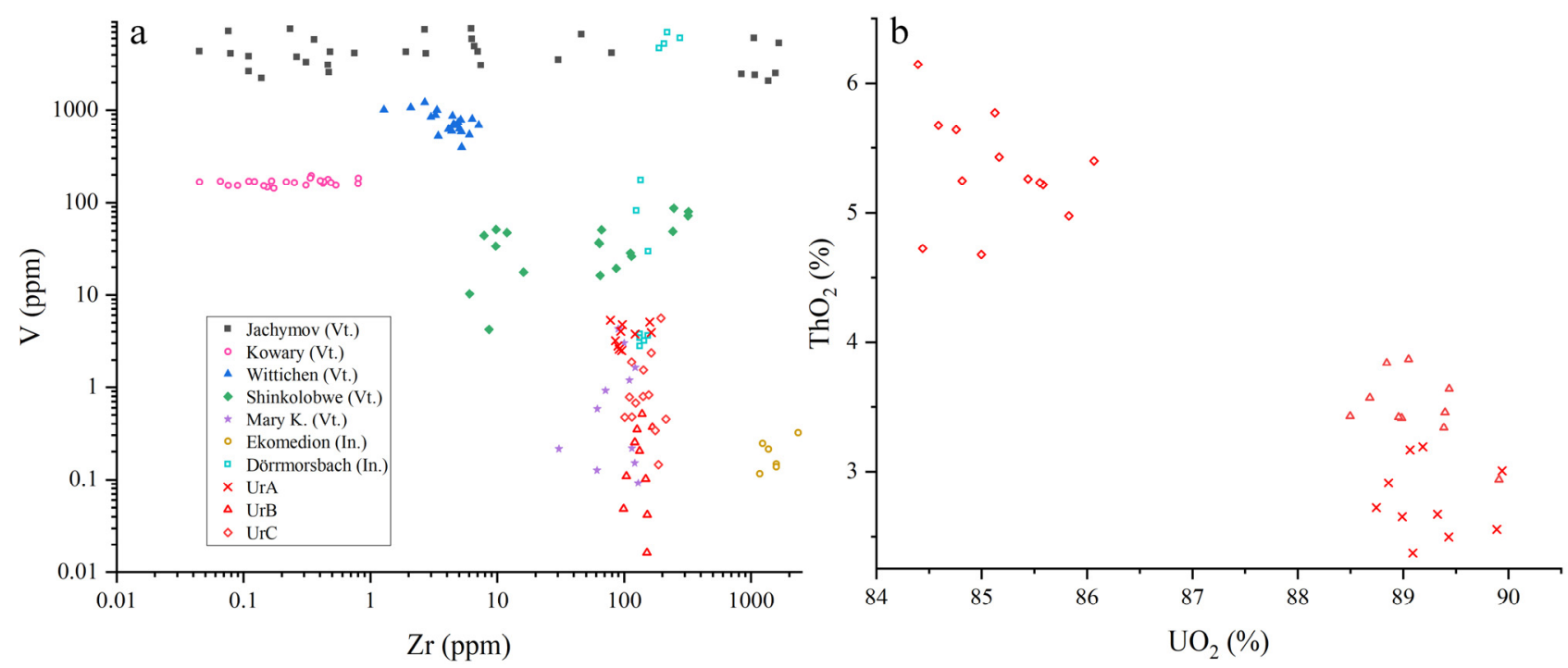

Figure 6. (a) V versus $\mathrm{Zr}$ content in uraninite from various types of deposit and UrA/UrB/UrC (data from Frimmel et al. [7] and this study), and (b) $\mathrm{ThO}_{2}$ versus $\mathrm{UO}_{2}$ content in uraninite from $\mathrm{UrA} / \mathrm{UrB} / \mathrm{UrC}$.

\subsection{Relationship between the Felsic and Quartz Veins}

Although the ore-bearing veins are not pegmatite, uraninite geochemical characteristics all show an intrusive type origin, which may be due to the relatively low metamorphic temperature (amphibolite facies) in the study area. Therefore, no Pegmatite-Alaskite similar to the Luoxin (Namibia) and Guangshigou (China) uranium deposits were formed. This can be demonstrated by the formation of euhedral dark minerals in the felsic vein. The dark euhedral minerals formed by plagioclase gneisses on both sides of metasomatic felsic veins during emplacement are mainly plagioclase and pyroxene. The corresponding metamorphic lithofacies is hornblende, indicating that the dark minerals were formed at medium - high temperatures (about $500{ }^{\circ} \mathrm{C}$ ) and medium - high pressure. This is consistent with the Guo et al. [24] result showing that the homogenization temperature of the inclusions in the felsic veins was concentrated at $380-540{ }^{\circ} \mathrm{C}$. The homogenization temperature of some primary inclusions in quartz veins tested by Guo et al. [24] was concentrated at $140-220^{\circ} \mathrm{C}$ in addition to high-temperature inclusions. This is inconsistent with the higher 
mineralization temperature reflected by the UrC geochemical characteristics. In contrast, we believe that the formation temperature of such inclusions may represent the lower limit of the formation temperature of uraninite. Thus, the formation of coarse-grained uraninite occurs during a slow decline from medium to high temperatures (about $500{ }^{\circ} \mathrm{C}$ ) to medium-low temperatures $\left(140-220^{\circ} \mathrm{C}\right)$.

The symbiotes closely related to uraninite in the felsic vein and quartz vein are apatite, sphene, and molybdenite, which may imply that the felsic and quartz veins have a certain genetic relationship. $\mathrm{UrA}, \mathrm{UrB}$, and $\mathrm{UrC}$ have the same REE distribution patterns, indicating that the felsic and quartz veins have the same genesis. By comparing the $\mathrm{ThO}_{2}$ content of uraninite in different veins (Figure 6b), it was found that the $\mathrm{ThO}_{2}$ content of $\mathrm{UrC}$ was significantly higher than that of UrA and UrB, which may indicate that the quartz vein was formed at a lower temperature resulting from the evolution of the felsic magma. The biggest limiting factor for the formation of large grained uraninite is the slow decrease in temperature [36]. The particle size of $\mathrm{UrB}$ formed in the quartz vein is relatively small (Figure 2g,h), while the particle size of $\mathrm{UrC}$ formed in the quartz vein can reach more than $1 \mathrm{~cm}$ (Figure $3 \mathrm{~b}, \mathrm{~d}$ ), which indicates that the formation of large grain uraninite is facilitated by the slow decrease of temperature during simple fractional crystallization combine the evidence mentioned above.

\subsection{Discussion on Genesis of Uraninite}

Because $\mathrm{U}$ in a silicate magma has a large ionic radius and high valence, it cannot easily enter the structure of the main rock-forming minerals. This leads to the preferential existence of $U$ in the silicate melt during the partial melting and crystal differentiation processes [37]. Theoretically, there are two methods to produce uranium-rich silicate rock masses. One method is the extreme differentiation of highly differentiated silicate magma, which is often regarded as Uranium-rich granite. Its uranium minerals exist in the form of accessory minerals and have small particles. Therefore, there are few reports on the formation of large-grained uraninite $[18,38]$. Another way to make silicate melts rich in uranium is by low-degree partial melting of the parent rock [39,40]. Mercadier et al. [40] proved that under very low partial melting $(<5 \%)$ conditions, the concentration of $U$ in a silicate melt can reach $300 \mathrm{ppm}$. Kukkonen and Lauri [41] used model calculations to prove that uranium can be enriched dozens of times in the parent rock under low-degree partial melting conditions. Therefore, even if the U content in the parent rock is normal, partial melting will cause the $U$ content in the melt to increase. Because of the similar geochemical properties of Th and $\mathrm{U}$, similar Th enrichment behavior also occurs under low-degree partial melting conditions [38,41].

$\mathrm{Qu}$ [28] studied the petrological and geochemical characteristics of major and trace elements, and the diagenetic ages of the main rock mass (Dingzhen rock mass) in the Haita area and classified these rock masses as hyper aluminous high-K calc-alkaline potassic basalt series of highly differentiated A2 granites. The Hf content in zircon has a positive correlation with magma evolution [42]. That is, the highly differentiated granite zircon is rich in Hf. By collecting the Hf content of zircons from different veins tested by the research team (unpublished data), it was discovered that the Hf content of zircon in the quartz vein is $8019.56-15,215.86 \mathrm{ppm}$ (mean $=11,139.80 \mathrm{ppm})$, while that in the felsic vein is $7546.19-13,563.58 \mathrm{ppm}$ (mean $=10,067.95 \mathrm{ppm})$. The Hf contents of zircons in the two veins are low, indicating that the magma had a low degree of evolution. The euhedral dark minerals in the felsic vein led to the metamorphic facies in the study area being defined as hornblende facies. Chen et al. [38] studied the Guangshigou uranium deposit and found that the hornblende facies is the key to the formation of uranium-rich pegmatitic magma, which is also applicable to the study area. The low Hf content of zircon indicates that the two veins were unrelated to the Dingzhen rock mass during genesis. Amphibolite facies limited by dark minerals indicate uranium mineralization in the study area during migmatization. Therefore, it is speculated that uranium mineralization in the study area is closely related to the partial melting of felsic material caused by migmatization. The 
combined research team found in previous research that the mica quartz schist and gneiss components of migmatite veins in the study area are para-metamorphic rocks formed by the metamorphism of sedimentary rocks. The U concentrations ranged from 5.64 to $12.90 \mathrm{ppm}$, with an average of $8.89 \mathrm{ppm}$. The average Th/U ratio of 2.97 falls within the range of values reported for U-rich rocks [22]. After the onset of migmatization, the $U$ concentrations of the granites formed by in situ anatexis of metamorphic rocks varied from 12.90 to $29.50 \mathrm{ppm}$, with an average of $21.30 \mathrm{ppm}$. The average Th concentration and average $\mathrm{Th} / \mathrm{U}$ ratio were $59.13 \mathrm{ppm}$ and 3.20 , respectively. These rocks, which belong to the U-rich granite body, reflect the completion of preliminary U enrichment during the migmatization process. The U-rich granite body is one of the most likely $\mathrm{U}$ sources linked to ore-forming fluid evolution in the study area. This is consistent with the conclusion of partial melting reflected in the geochemical characteristics of uraninite [22].

The low degree of partial melting of feldspathic materials during the migmatization may be the most important mechanism for uranium mineralization in the study area and even in the western margin of the Yangtze Block. Further simple fractional crystallization may be another important mechanism for the formation of megacrystalline uraninite.

\section{Conclusions}

The REE distribution patterns, the variation of $\mathrm{ThO}_{2}$ content, particle size, and the syngenetic assemblage of megacrystalline uraninite indicate that the quartz vein and felsic vein are related in genesis, and that the quartz vein may have formed by simple evolutionary differentiation of felsic magma.

We suggest that genesis of megacrystalline uraninite can be classified into the subtype of Pegmatite-Alaskite under intrusive type, which is formed by partial melting in hightemperature and low-pressure environments.

This study enriches the REE database of uraninite in uranium deposits worldwide, which is meaningful for studying the genesis of megacrystalline uraninite.

Supplementary Materials: The following are available online at https:/ /www.mdpi.com/article/10.3390/ min11111173/s1, Table S1: Chemical composition of megacrystalline uraninite.

Author Contributions: Conceptualization, Z.X. and M.Y.; methodology, L.X. and H.G.; software, H.G.; validation, Y.C., H.S. and C.Z.; formal analysis, M.Y.; investigation, J.Y.; resources, Z.X.; data curation, M.Y. and J.Y.; writing-original draft preparation, Z.X. and M.Y.; writing-review and editing, Z.X. and M.Y.; visualization, M.Y. and L.X.; supervision, Y.C.; project administration, Z.X.; funding acquisition, Z.X. All authors have read and agreed to the published version of the manuscript.

Funding: This study was financially supported by the Everest Scientific Research Program of Chengdu University of Technology (No. 2021ZF11413), The National Natural Science Foundation Program of China (No. 41872079, 42072096), The Applied Basic Research Program of Sichuan Province, China (No. 20YYJC2305), the Program of China National Uranium Company Limited (No. 20217).

Institutional Review Board Statement: Not applicable.

Informed Consent Statement: Not applicable.

Data Availability Statement: Data is contained within the article and Supplementary Materials.

Acknowledgments: We greatly appreciate the help of Jiaming Qi, Zhibo Zhang, Guangwen Huang, and Pengfei Fan during daily discussion work.

Conflicts of Interest: The authors declare no conflict of interest.

\section{References}

1. Dahlkamp, F.J. Uranium Ore Deposits; Springer: New York, NY, USA, 1993; p. 450.

2. Cuney, M. The extreme diversity of uranium deposits. Miner. Deposita 2008, 44, 3-9. [CrossRef]

3. Cuney, M. Uranium and Thorium: The Extreme Diversity of the Resources of the World's Energy Minerals; Springer: New York, NY, USA, 2012; p. 39. 
4. IAEA. World Distribution of Uranium Deposits (UDEPO) with Uranium Deposit Classification: IAEA-TECDOC-1843; International Atomic Energy Agency: Vienna, Swiss, 2016; pp. 1-3.

5. IMA. List of Minerals. In Commission on New Minerals, Nomenclature and Classification; International Mineralogical Association: Paris, France, 2021; p. 219.

6. Shannon, R.D. Revised effective ionic radii and systematic studies of interatomic distances in halides and chalcogenides. Acta Crystallogr. Sect. A Cryst. Phys. Diffr. Theor. Gen. Crystallogr. 1976, 32, 751-767. [CrossRef]

7. Frimmel, H.E.; Schedel, S.; Brätz, H. Uraninite chemistry as forensic tool for provenance analysis. Appl. Geochem. 2014, 48, 104-121. [CrossRef]

8. Janeczek, J.; Ewing, R. Structural formula of uraninite. J. Nucl. Mater. 1992, 190, 128-132. [CrossRef]

9. Grandstaff, D.E. A kinetic study of the dissolution of uraninite. Econ. Geol. 1976, 71, 1493-1506. [CrossRef]

10. Reimer, T.O. The Late-Archean Dominion conglomerates (South Africa): New aspects of their derivation and their relationship with those of the Witwatersrand. Neues Jahrb. Geol. Pa. 1987, 158, 13-46.

11. Bea, F.; Mitchell, J.N.; Scoates, J.S.; Frost, C.D.; Kolker, A. Residence of REE, Y, Th and U in Granites and Crustal Protoliths; Implications for the Chemistry of Crustal Melts. J. Pet. 1996, 37, 521-552. [CrossRef]

12. Fryer, B.J.; Taylor, R.P. Rare-earth element distributions in uraninites: Implications for ore genesis. Chem. Geol. 1987, 63, 101-108. [CrossRef]

13. Pagel, M.; Pinte, G.; Rotach-Toulhoat, N. The rare earth elements in natural uranium oxides. In Uranium Mineralization-New Aspects on Geology, Mineralogy, Geochemistry, and Exploration Methods; International Atomic Energy Agency: Vienna, Austria, 1987; pp. $1-320$.

14. Maas, R.; McCulloch, M. A search for fossil nuclear reactors in the Alligator River Uranium Field, Australia: Constraints from Sm, Gd and Nd isotopic studies. Chem. Geol. 1990, 88, 301-315. [CrossRef]

15. Hidaka, H.; Holliger, P.; Shimizu, H.; Masuda, A. Lanthanide tetrad effect observed in the Oklo and ordinary uraninites and its implication for their forming processes. Geochem. J. 1992, 26, 337-346. [CrossRef]

16. Hidaka, H.; Gauthier-Lafaye, F. Neutron capture effects on Sm and Gd isotopes in uraninites. Geochim. et Cosmochim. Acta 2001, 65, 941-949. [CrossRef]

17. Mercadier, J.; Cuney, M.; Lach, P.; Boiron, M.-C.; Bonhoure, J.; Richard, A.; Leisen, M.; Kister, P. Origin of uranium deposits revealed by their rare earth element signature. Terra Nova 2011, 23, 264-269. [CrossRef]

18. Hazen, R.M.; Ewing, R.C.; Sverjensky, D.A. Evolution of uranium and thorium minerals. Am. Miner. 2009, 94, $1293-1311$. [CrossRef]

19. Zhang, C.J.; Chen, Y.L.; Li, J.C.; Xu, Z.Q.; Yao, J. The discovery of coarse-grained uraninite in Kangdian Axis and its geological significance. Geol. Bull. China 2015, 34, 2219-2226. (In Chinese with English Abstract)

20. Wang, F.G.; Sun, Y.; Yao, J.; Ye, J.L. Study on characteristics of gaint grain uraninite in Haita area of Miyi County, Sichuan. World Nuclear Geosci. 2017, 34, 187-193. (In Chinese with English Abstract)

21. Wang, F.G.; Yao, J. A new consideration on the genesis of uranium mineralization in Mouding, Yunnan: A new mineralization type related to albitite. Geol. Rev. 2020, 66, 739-754. (In Chinese with English Abstract)

22. Chang, D. Geological and Geochemical Characteristics of Migmatite Type Uranium Deposit in the Haita area, Miyi Town, Sichuan Province. Master's Thesis, Chengdu University of Technology, Chengdu, China, 2016. (In Chinese with English Abstract)

23. Liu, K.P. Mineralization Physical and Chemical Conditions of Uranium Deposit in Haita area, Miyi County, Sichuan Province. Master's Thesis, Chengdu University of Technology, Chengdu, China, 2017. (In Chinese with English Abstract)

24. Guo, R.; Chen, Y.L.; Liu, K.P.; Zheng, Y.W.; Hu, Y. Characteristics of fluid inclusions in quartz of the haita migmatite type uranium deposit in Miyi county, Sichuan province, China. Ac. Mineral. Sin. 2020, 40, 137-148. (In Chinese with English Abstract)

25. Yin, M.; Xu, Z.; Song, H.; Zhang, C.; Zhang, S.; Tian, J.; Guo, H. Constraints of the geochemical characteristics of apatite on uranium mineralization in a uraninite-rich quartz vein in the Haita area of the Kangdian region, China. Geochem. J. 2021, 55, 301-312.

26. Sun, Y.; Yao, J.; Li, J.; Sun, Z. Mineralization Characteristics and Origin of Extra Rich Uranium Deposits in Miyi-Yuanmou Area, Middle-South Part of Kangdian Earth's Axis. Uranium Geol. 2021, 37, 466-475. (In Chinese with English Abstract)

27. Li, W. Migmatization and Uranium Mineralization in Haita Area of Miyi in Sichuan Province. Uranium Geol. 2018, 34, 346-352. (In Chinese with English Abstract)

28. Qu, L. Chronology and Geochemical Characteristics of Dingzhen Complex in Miyi District, Sichuan Province. Master's Thesis, Chengdu University of Technology, Chengdu, China, 2019. (In Chinese with English Abstract)

29. Zeng, M.; Zhang, D.; Zhang, Z.; Li, T.; Li, C.; Wei, C. Structural controls on the Lala iron-copper deposit of the Kangdian metallogenic province, southwestern China: Tectonic and metallogenic implications. Ore Geol. Rev. 2018, 97, 35-54. [CrossRef]

30. Song, H.; Chi, G.; Zhang, C.; Xu, D.; Xu, Z.; Fan, G.; Zhang, G. Uranium enrichment in the Lala Cu-Fe deposit, Kangdian region, China: A new case of uranium mineralization associated with an IOCG system. Ore Geol. Rev. 2020, 121, 103463. [CrossRef]

31. Zhu, L.; Liu, J.; Bagas, L.; Zhai, D.; Meng, G.; Verrall, M. New insights into the genesis of IOCG deposits: From a case study of the Yinachang deposit in SW China. Ore Geol. Rev. 2020, 124, 103664. [CrossRef]

32. Hu, Z.C.; Zhang, W.; Liu, Y.S.; Gao, S.; Li, M.; Zong, K.Q.; Chen, H.H.; Hu, S.H. “Wave” signal smoothing and mercury removing device for laser ablation quadrupole and multiple collector ICP-MS analysis: Application to lead isotope analysis. Anal. Chem. 2015, 87, 1152-1157. [CrossRef] [PubMed] 
33. Liu, Y.; Hu, Z.; Gao, S.; Günther, D.; Xu, J.; Gao, C.; Chen, H. In situ analysis of major and trace elements of anhydrous minerals by LA-ICP-MS without applying an internal standard. Chem. Geol. 2008, 257, 34-43. [CrossRef]

34. Cuney, M. Evolution of Uranium Fractionation Processes through Time: Driving the Secular Variation of Uranium Deposit Types. Econ. Geol. 2010, 105, 553-569. [CrossRef]

35. Anders, E.; Grevesse, N. Abundances of the elements: Meteoritic and solar. Geochim. et Cosmochim. Acta 1989, 53, 197-214. [CrossRef]

36. Yao, L.Y.; Zhang, B.J. Experimental Geochemistry of the Xiangshan Hydrothermal Uranium Deposit; Atomic Energy Press: Beijing, China, 2014; p. 54. (In Chinese)

37. Potter, E.G. Michel Cuney and Kurt Kyser: Geology and Geochemistry of Uranium and Thorium Deposits. Miner. Deposita. 2017, 133-134. [CrossRef]

38. Chen, Y.; Hu, R.; Bi, X.; Luo, J. Genesis of the Guangshigou pegmatite-type uranium deposit in the North Qinling Orogenic Belt, China. Ore Geol. Rev. 2019, 115, 103165. [CrossRef]

39. Robb, L. Introduction to Ore-Forming Processes; Blackwell Publishing: Malden, MA, USA, 2004; p. 373.

40. Mercadier, J.; Annesley, I.R.; McKechnie, C.L.; Bogdan, T.S.; Creighton, S. Magmatic and Metamorphic Uraninite Mineralization in the Western Margin of the Trans-Hudson Orogen (Saskatchewan, Canada): A Uranium Source for Unconformity-Related Uranium Deposits? Econ. Geol. 2013, 108, 1037-1065. [CrossRef]

41. Kukkonen, I.; Lauri, L. Modelling the thermal evolution of a collisional Precambrian orogen: High heat production migmatitic granites of southern Finland. Precambrian Res. 2009, 168, 233-246. [CrossRef]

42. Wang, R.C.; Fontan, F.; Shijin, X.; Xiaoming, C.; Monchoux, P. Hafnian zircon from the apical part of the Suzhou granite, China. Can. Miner. 1996, 34, 1001-1010. 